\title{
CONFLICT MANAGEMENT IN THE CANADIAN FEDERAL SYSTEM
}

\author{
J.R. MALLORY*
}

A retired Canadian cabinet minister, speaking at a departmental seminar at McGill University last year, asked the question "Why does federal-provincial conflict in Canada loom so large in contrast to federal-state conflict in the United States?" The simple answer to that question was that the separation of powers in the United States diffuses power-between the President and the Congress, between governors and state legislatures - in such a way that any conflict which takes place is widely distributed throughout the system. In Canada the system of cabinet government concentrates power in the executive-the Prime Minister and Cabinet in Ottawa and the provincial premiers and their cabinets in their respective provinces. In this way, the conflict is focused on a small universe of more or less monolithic actors. The fact that there are only ten provinces in Canada as against fifty states in the United States may also have a bearing on the intensification of the conflict. The difference in the systems of government-congressional on the one hand and the Westminster model on the other-has a great deal to do with the focus and resolution of conflicts in the two systems. In Canada the two principal institutions for conflict management-the courts and intergovernmental negotiation-differ considerably from their counterparts in the United States.

\section{Is Federalism Inconsistent With the Westminster Model?}

Canada is not the only country which has attempted to marry a parliamentary system of government with federalism. Australia has done the same thing, and a number of other countries within the British Commonwealth have followed suit. Over eighty years ago the founders of the Australian federal system were seriously concerned with whether the two systems could be united, and some wondered whether either federalism or the Westminster system would prevail to the exclusion of the other system. ${ }^{1}$ In the case of Australia, the fear was that the elected Senate would be capable of destroying a government with a stable majority in the lower house, and something like this happened in $1975^{2}$ The essence of the Westminster system is that the executive has the authority to govern as long as it is supported by a majority in the popularly elected lower house, and is thus responsible to it. If a second chamber representing a different constituency-the states as

\footnotetext{
Copyright (C) 1981 by Law and Contemporary Problems

* R.B. Angus Professor of Political Science, McGill University

1. See Archer, The Theory of Responsible Government in Britian and Australia, in RESPONSIBLE GoverNMENT IN Australia 23 (P. Weller \& D. Jaensch eds. 1980).

2. See generally G. SaWer, Federation Under Strain: Australia 1972-1975 (1977).
} 
such-can bring government to a standstill by refusing to pass appropriations, the stability and workability of the system is at risk.

This has so far not been the problem in Canada because the Canadian Senate is a nonelective body which has used its powers with circumspection. The incompatibility of the two systems has emerged elsewhere in the form of conflicts between the provinces and the central government which no existing institutions in the political system seem to be able to resolve. This sort of conflict may well be visible in Australia as well.

One of the obvious features of the Westminster system was what Walter Bagehot called "the close union, the nearly complete fusion, of the executive and legislative powers." 3 This has meant that a government, once confirmed in power by a general election, can count as long as that parliament lasts on the strict discipline of its majority in the House to free it from the risk that its proposals will be modified by the legislature. This is a tremendous concentration of power only mitigated by the extent to which an opposition can frustrate a government by delaying tactics. Governments in the Westminster system are not only groups of politicians who command and wish to enhance great resources of political power, but also bureaucracies which have their own reasons for aggrandizing the jurisdiction of their bureaucratic empires. In a federal state the distribution of legislative power describes the boundary line within which governments and legislatures are circumscribed by the constitution. Thus the governments at the two levels are engaged in perpetual conflict over the placement of the boundary. Increasing demands on government as a result of changing social values result in a need to decide which level of government should deliver the services in question.

II

\section{Constitutional Adjustment in Federal Systems}

Constitutional adjustment, in its broadest sense, involves the incorporation of important changes in community values into the legal and governmental system. When a constitution imposes no barriers this change may take place simply through legislative change. ${ }^{4}$ In federal systems the constitution, to an extent frozen in the values of the age in which it was written, may impose barriers to such substantial changes. Appropriate policy changes may only be possible by a change in the distribution of power between the levels of government. To accomplish this by the painful and uncertain method of constitutional amendment may be either long delayed or impossible. An alternative method, as Dicey pointed out, is for the courts to articulate authoritatively a new constitutional adjustment.

That a federal system again can flourish only among communities imbued with a legal spirit and trained to reverence the law is as certain as can be any conclusions of political speculation. Federalism substitutes litigation for legislation, and none but a law-fearing people will be inclined to regard the decision of a suit as equivalent to the enactment of a

3. W. Bagehot, The English Constitution 65 (1963).

4. See, e.g., A. Dicey, Law and Opinion in England During the Nineteenth Century (1962). Dicey demonstrated the shift to laissez-faire and then toward collectivism, and traced these changes into the statute books. 
law. ${ }^{5}$

Thus, in Canada, as in the United States, the courts are the fulcrum of constitutional change. In any process of change there are winners and losers. Changes in political ideas push their way through the political process to drive governments to enact laws which adversely affect vested interests of one group or another. If these be powerful economic interests they are likely to be overwhelmed in the end by the democratic process, but their powers of resistance are not exhausted. They have the financial resources to fight long battles in the courts, ostensibly in defense of constitutional principle, to defeat laws they find repulsive. ${ }^{6}$

There are, however, significant differences between the Constitutions of Canada and the United States which provide different strategies to the actors. One difference is the existence in the United States of a Bill of Rights in the Constitution, and its absence (at least so far) in Canada. Thus in the United States vested interests on the defensive, or citizens' groups seeking their objectives when normal political means have failed, can involve the courts in order to restrain under the Bill of Rights the enforcement of laws they do not like. This expedient is, on the whole, not possible in Canada where the only litigious ground is legislative jurisdiction. That is why it was necessary to fight the wartime and post-war treatment of Japanese Canadians solely on the ground of whether the Parliament of Canada possessed such jurisdiction under emergency legislation. ${ }^{7}$ Similarly, a long line of civil liberties cases in Quebec had to be fought on the ground that the province was invading the criminal law power of Parliament. ${ }^{8}$

In Canada the great conflict over the jurisdiction of the two levels of government seems to have died down after the Second World War. The reason for this was twofold. First, the war and postwar economy had led to much closer relationships between the board rooms of the great corporations and governments. The managers of these corporations were less likely to be closeted with their legal advisers seeking to upset legislation and more likely to be seeking benefits from governments. Unable to beat the big battalions in the courts, they now preferred to work with them for mutual advantage. Second, the courts also affected this decline. In the prewar years courts had been much more inclined to find against legislation which they did not like, but later became more accommodating to the growing requirements of the modern state in regulating the economy, whether that state took the form of a provincial legislature or of the Parliament of Canada. In the process they had escaped from the "watertight compartment" view of the distribution of legislative powers and had come to cast a benevolent eye on legislation in fields of overlapping jurisdiction which sought to achieve a unified system of control through administrative delegation of enforcement power from one sovereign legislature to the agents of the other. A classic case is Prince Edward Island Potato Marketing Board v. H.B. Willis, Inc. , ${ }^{9}$ which permitted the government of Canada to

\footnotetext{
5. A. Dicey, INTROduction to THE StUdy of THE LAW OF THE CONSTITUTION 179 (1961).

6. See genetally J. Mallory, Social. Credit and the Federal Power in Ganada $181-98$ (1954).

7. Cooperative Comm. on Japanese-Canadians v. Attorney Gen. of Can. [1947] 1 D.L.R. 577 (1946).

8. See F. ScotT, Civil Liberties and Canadian Federalism (1959).

9. [1952] 2 Can. S. Ct. 392.
} 
"adopt as its own" a provincial marketing board for the purpose of enforcing the regulation of interprovincial and international trade in an agricultural commodity.

The development of a large number of jointly financed and jointly administered programs in such fields as social security and public health were the result of federal initiatives in fields that were wholly or partly in provincial jurisdiction. This neatly avoided the apparent constitutional barrier against the achievement of common programs and common standards which applied throughout the country. ${ }^{10}$ That constitutional barrier had, in the prewar years, seemed insuperable. If such programs were to apply generally across the country a constitutional amendment to transfer such a large area of jurisdiction from the provinces to the federal government could never have commanded sufficient political support to make it possible, while an alternative under which the provinces might delegate jurisdiction to the federal parliament was firmly rejected by the Supreme Court of Canada. ${ }^{11}$

Thus, the federal-provincial conference became the major innovation in the Canadian federal system during the postwar years. This wholly informal and extraconstitutional device took many forms. At the summit of the process is the First Ministers' Conference. This body, presided over by the Prime Minister, includes all of the provincial premiers. The principal participants are usually accompanied by their Ministers of Intergovernmental Affairs, other ministers if the subject warrants, and the normal bevy of civil service advisers. There are also regular meetings of ministers covering particular fields. Such meetings are usually supported by continuing meetings of officials to deal with more technical topics and prepare the ground for further ministerial meetings.

What are the outcomes of all these meetings which consume thousands of manhours? A vast range of matters of joint concern to the two levels of government are discussed and bargained over, from constitutional amendments, tax-sharing, and the joint funding of shared programs, to the reconciliation of legal norms. A striking characteristic of this phenomenon is that a wide range of public policy issues is worked out through the process of secret negotiation and then presented to Parliament and the provincial legislatures in agreed form for ratification, so that the normal legislative process of debate and open compromise is replaced by agreements which are no longer negotiable by the time they become public. ${ }^{12}$ This system of executive federalism, as it is called, has had the effect of vastly strengthening the executive at the expense of the legislature, and the significance of this has not been lost on those who publicly mourn the decline in the influence and role of Parliament.

What were the perceived advantages in the procedure? It did make possible

10. Reference Re Weekly Rest In Industrial Undertakings Act, Minimum Wages Act and Limitation of Hours of Work Act, [1937] 1 D.L.R. 673. Lord Atkin stated that under the scheme of the British North America Act, there were to be "water-tight compartments which are an essential part of her original structure." Id. at 684 .

11. Attorney Gen. of N. S. v. Attorney Gen. of Can., [1951] Can. S. Ct. 31.

12. See generally R. Simeon, Federal Provincial Diplomacy (1972); D. Smiley, Canada in QuesTION: FEDER ALISM IN THE EIGHTIES (1980). 
solutions to problems created by the need to fit modern demands on the state into a constitutional framework designed in the very different conditions of the nineteenth century. The essence of the problem was that only the federal government had the fiscal resources to support such programs, which were beyond the means of all but the richest provinces, and totally beyond the means of most provinces, even though the constitutional division of powers placed these matters wholly in provincial hands. A tolerable result could be achieved by intergovernmental cooperation without the trauma and frustration of seeking a constitutional amendment. Resort to the courts to find a solution to jurisdictional difficulties, on the other hand, had all of the characteristics of a zero-sum game, which neither party was prepared to risk.

One of the most striking of these developments was a change in the balance of sophistication between the two levels of government. At the beginning of the period the federa: government had emerged from the war with a large, experienced and expert bureaucracy to support policy innovation and implementation by ministers. All provinces, without exception, came out of the war with small, old-fashioned bureaucratic structures unable to match their federal counterparts in knowledge, and in this case clearly knowledge led to power. The mere necessity of developing the accounting and control procedures sufficient to manage programs up to federal standards was enough to bring about an improvement in the administrative capacity of the provinces. It was only the next step for the provinces to perceive that the bulk of their own resources were being committed to suit federal priorities in programs funded by matched grants. ${ }^{13}$ As the provinces built up their own staffs of experts they became more capable of bargaining with their federal counterparts on equal intellectual terms. By the time of the negotiation over the Canada Pension Plan in 1963 and 1964, the provincial experts were clearly better prepared than their federal counterparts and succeeded in radically altering the original federal proposal. This growth in provincial bureaucratic capability should not be underestimated as a major factor in the decentralization of the Canadian federal system in the last two decades.

The system of federal adjustment by negotiation became so pervasive that it appeared to be displacing the courts as the chief mechanism of adjustment in the system. The figures for constitutional cases before the supreme court are illustrative. "From 1950 . . . to 1974, the Supreme Court of Canada disposed of fifty-nine constitutional cases, an average of only 2.5 a year. Since 1975 it has risen somewhat."14 The reason in part was a distrust of the court by some (perhaps most) provincial governments. The Supreme Court of Canada is not entrenched in the Constitution, but created by Parliament by virtue of section 101 of the British North America Act (B.N.A.) ${ }^{15}$ which enables it to "provide for the Constitution, Maintenance, and Organization of a General Court of Appeal for Canada." What

13. For example, federal policies committed very large resources in the early period to improvements in health care, leaving the provinces with inadequate funds to deal with education, which for political reasons was not a federal priority.

14. Hogg, Jurisdiction of the Courts: The Supreme Court of Canada, 3 CAN. U.S. L.J. 39, 44 (1980).

15. The British North America Act, 1867, 30 \& 31 Vict., c. 3 [hereinafter cited as B.N.A. ACT]. 
Parliament has created, it could presumably enlarge, modify, or destroy without reference to the provinces. The judges of the court are appointed by the federal Cabinet, without the necessity of any provincial participation in the process, or any ratification procedure. This makes the authority of the court suspect. ${ }^{16}$ Provincial politicians distrust a court made up of judges wholly appointed by their adversary in constitutional conflict and such suspicion undermines the authority of the court in making decisions generally accepted as final and binding. ${ }^{17}$

Intergovernmental bargaining as an alternative to resort to the courts as a way of managing conflict has been successful in a number of situations where inappropriate jurisdictional boundaries prevented the implementation of generally agreed upon programs, for example, in creating universally accessible programs of health and hospital care and pensions for the aged. However, a grave problem has been created for the federal government by making the provinces the effective administrative agencies of programs for which the federal authorities have a major and increasing financial responsibility. The real growth of the economy has come almost to a dead stop, while costs due to inflation are rising, thus pushing up the federal deficit. Controling this deficit is almost impossible when approximately 57 percent of federal expenditure is committed to statutory obligations, the major components of which are established fiscal transfer programs and debt charges. Most fiscal and tax transfer programs are negotiated with the provinces on a five year basis and many of the major ones expire in 1982. Severe federal retrenchment would transfer heavier burdens to the provinces and threaten chaos to many established programs. This adds greatly to the atmosphere of tension and unease in all current federal-provincial negotiations.

There is a further difficulty with the system of federal adjustment by negotiation which has been described by the generic name of executive federalism. When it has worked in the past, the interests of the two levels of government were complementary. They shared the same objectives and could agree on the best policy and adminstrative outcome. It simply will not work when their objectives are not congruent, and no one should expect it to do so. It is likely that divergent federal and provincial interests will emerge in the 1980s. Probable areas of divergence include a policy on the control of foreign investment, a common industrial strategy, and particularly energy and resource problems.

\section{III}

\section{The Present Constitutional Impasse}

The constitutional debate which has dominated the Canadian scene for the past year involves all of the factors discussed above. It involves fundamental conflicts of value, both in the way the Constitution has and should recognize the position of French Canadians, and the relative positions of legislatures and courts in

16. One commentator has argued, however, that such suspicion is unwarranted. W. LEDERMAN, Continuing Canadian Constitutional Dilemmas 203 (1981).

17. See Mallory, Constraints on Courts as Agencies of Constitutional Change: The Canadian Case, 1977 PuB. L 404, 425-26. 
the final determination of community values; it involves a struggle over which level of government under the Constitution should control the economic destiny of the regions of Canada. Useful constitutional debates hinge on agreement about the rules governing the determination of ultimate values and about the location of political power.

A number of issues have converged and have become inextricably intermingled. Patriation is a Canadian neologism which refers to the process of actually bringing the Canadian Constitution to Canada. Since the creation of the Canadian federation in 1867, the basic Canadian document has been the B.N.A. Act-a statute of the British Parliament. One of the lacunae in that Act was the possibly deliberate omission of a general amending power, though it has always been true that some parts of the Constitution could be amended in Canada.

A great deal is at stake in deciding who is involved in this process. In issues which did not affect the powers of the provinces under the Constitution, the historic practice was for a joint resolution of the Senate and the House of Commons to request the British Parliament to act by bringing about the necessary amendment. Where provincial powers were concerned, it had become customary to consult with and secure agreement from all of the provinces before the Canadian Parliament proceeded to seek an amendment. Whether this had become a rigid convention of the Constitution was a matter of some disagreement among the authorities. One thing is clear. The Statute of Westminster of $1931,{ }^{18}$ which removed all constitutional limitations on the sovereignty of the British Dominions, would have given legal force to the established convention that the British Parliament would not pass any law affecting them except with their consent and at their request. This would have apparently transferred the power to amend the B.N.A. Act to the Parliament of Canada. Resultant objection from provincial governments led the Canadian government to secure a clause in the Statute of Westminster ${ }^{19}$ exempting the B.N.A. Acts from the effect of the Statute. It was assumed that in due course, agreement in Canada on an amending formula would be found and the liberation of Canada from this form of British tutelage would be achieved. So far no formula has been found. Meanwhile, what is the role of the British Parliament? Has it the moral and constitutional right to look behind the form to the substance of a request of the Canadian Parliament, or is its role purely formal and automatic? That is what part of the debate is about.

There have been numerous attempts to reach agreement on an amending formula so that the final constitutional link with the British Parliament could be cut and the Canadian Constitution reasserted in purely Canadian form. All of these attempts have failed. In one case, the federal-provincial conference of first ministers at Victoria, British Columbia, in 1971, tentative agreement of all governments concerned was actually achieved, only to have this agreement repudiated by Quebec after the Premier had returned to his native province.

The Quebec problem was, and is, one of the keys to the difficulty. The modern-

18. The Statute of Westminster, 1931, 22 Geo. 5, c. 4.

19. 22 Geo. 5, c. $4, \S 7$. 
ization of Quebec society, particularly since the 1960s, has made it more urgent to define explicitly the special position of Quebec in the Constitution. The B.N.A. Act did so only in relation to the civil law in that province and the equality of the French and English languages in the legislatures and courts of Quebec and Canada. Modern governments with ever increasing demands to assume responsibility for cultural and social matters require more than that. In the case of Quebec the sensitive areas have been social policy and communications. All of this, of course, was brought to a head with the election of a separatist government in Quebec in 1976 and the Quebec Referendum on negotiation of "sovereignty-association" for that province in 1980. In the course of the referendum debate, urgent promises of "constitutional renewal" were made by the proponents of the "no" vote. Having won, with almost 60 percent of the votes, they would have to be under an obligation to deliver. Accordingly, a series of urgent prelimiary negotiations took place between federal and provincial ministers over the summer to prepare for a summit of first ministers in September. The preparatory negotiations seemed to make substantial progress. The summit failed. To understand this failure, it is imporant to look at the issues as perceived by the principal protagonists. Years of refinement of the Westminster system, coupled with the long-standing format of executive federalism, meant that the first ministers alone had the political power to settle the question. If they settled it, no legislature would have ventured to contradict them.

For a majority of provincial first ministers the focus of the issues was not Quebec, but increased powers over their provincial economies. This was a particularly acute issue for the four Western provinces, the majority of which had resourcebased prosperity which, in the case of oil and minerals, was of course a rapidly wasting asset. Could they use their new wealth to build an industrial base in the West and challenge the historic pattern of the Canadian economy? The concentration of population and industry in Ontario and Quebec had meant that Western raw materials and agricultural production were financed and processed in the East. A combination of what the Australians call "numbers" (population and thus majority domination of Parliament and the Cabinet) and economic power had produced what the political economists see as the classic metropolis-periphery dependency relationship. The provincial premiers from the periphery represented regions that were politically weak in Ottawa, but at the summit conference they had the numbers and the bargaining power in a situation whch was customarily governed by consensus.

Buoyed by poll results and bound by their own promises, the federal politicians decided to move ahead on constitutional reform without provincial agreement. In large measure this was the result of the determination of Prime Minister Trudeau himself - a man of limited patience with people whom he regards as unreasonable. What are the constitutional implications of his action? As the Chief Justice of Manitoba said, "The attempt by the Federal power to patriate the constitution unilaterally may be an act of high statesmanship or of political folly. This is not a determination that we are called upon to make."20

20. Reference Re Amendment of the Constitution of Canada, 117 D.L.R.3d 1, 11 (1981). 
Undeterred by the failure to secure agreement on a number of issues which could have led to a substantially revised. Constitution embodied in a final amendment to the B.N.A. Act by which the British Parliament would at the same time terminate the need for its further involvement in the process, the federal government introduced a joint resolution into both Houses of Parliament in October. After some debate, the resolution was referred to a Joint Committee of both Houses. After two extensions of time, the Committee reported the resolution back to both Houses on February 13, 1981, for final debate. This debate was frustrated by a variety of procedural devices by the Opposition in the House of Commons, and it was finally agreed that the concluding debate in both Houses on the resolution would be held after the Supreme Court of Canada had ruled on the constitutionality of the resolution. Three provinces (Manitoba, Quebec and Newfoundland) had challenged the resolution in the courts, and appeals from the three decisions were heard by the supreme court in May and the decision was rendered on September 28. ${ }^{21}$

\section{IV}

\section{Constitutional Issues Raised by the Trudeau Package}

In essence, the proposal for constitutional reform embodied the following: the final termination of the process of amendment by the Parliament of the United Kingdom ("patriation"); the inclusion in the new Constitution of a Bill of Rights, embodying both the usual civil and political rights and also the right of minorities to education in whichever of the official languages is the minority language in the province in which they live; a constitutional guarantee of the principle of equalization (i.e., that Parliament is obliged to ensure that all provinces are financially able to provide essential public services "without imposing an undue burden of provincial taxation"); and provision for an amending formula. All of these proposals had been on the constitutional agenda for years, and many of them have wide support. One thing is certain, they embody the essential constitutional reforms that Prime Minister Trudeau has consistently espoused throughout his political life. Objection to the proposals, initially led by a number of provincial premiers, was that the method departed too abruptly from the intergovernmental consensus which, to them, appeared to be the central feature of confederation. Nevertheless, the proposals also raise a number of constitutional issues.

Some of these relate to the conventions of the Constitution, rather than to the law of the Constitution, and thus may not lend themselves to authoritative decision in the courts. The process itself requires the clarification of two such matters, one relating to the United Kingdom and the other to Canada. The former hinges on the role of the British Parliament since the Statute of Westminster; section 4 of that act sought to enshrine an existing convention of the British Constitution that British acts of Parliament affecting the dominions should be at their request and with their consent. Does there nevertheless remain a discretion in the British Parliament to refuse or modify such requests, or is its role now purely that of a rubber

21. Reference Re Amendment of the Constitution of Canada, 125 D.L.R.3d 1 (1981). 
stamp? Of course in theory no British Parliament is bound by the actions of its predecessors so that the Statute of Westminster itself could be unilaterally repealed. The authorities differ over whether the Statute of Westminster is a limitation on the sovereignty of the British Parliament, or merely a rule of construction for the guidance of the courts. ${ }^{22}$ Must the British Parliament accept a formal request from Canada, or does it have the right to demur if a province protests that the proposed amendment violates rights or powers it possesses under the Constitution? Perhaps the one clear conclusion in the whole matter is that British ministers have repeatedly asserted that the role is automatic and they have in fact regarded the provinces as not having locus standi to be heard. ${ }^{23}$ Nevertheless a situation has never arisen before when the protest has come from more than one province, and the fact that as many as eight out of the ten are objecting may have some significance.

This difficulty has not escaped attention in Great Britain. Considerable provincial lobbying in London led the Select Committee on Foreign Affairs of the British House of Commons to take this factor into account. While these newly established British Committees have no legislative power, their reports are likely to have some influence on the British Government, particularly in estimating the degree of parliamentary difficulty which might be encountered. In its first Report of January 21, 1981, the Foreign Affairs Committee had argued that the British Government still had a responsibility in these matters and should refuse to implement the proposed amendment if it thought it was procedurally defective. ${ }^{24}$ This position was clarified in a second Report, dated April 15, when they emphasized that what they meant was not to pass judgment on the substance of the request but only on whether the request was made "in a proper manner". ${ }^{25}$ They concluded that "the UK Parliament need not automatically accede to the request unless the request is made with an appropriate level and distribution of Provincial concurrence." In their view the proposal had not followed the federal principle and was thus tainted.

The British Select Committee thus touched on the question of internal procedure in Canada. The Statute of Westminster does not say who has the authority to make requests for constitutional amendment. Some early ones were made at the request of the federal government alone. The practice in general for the past century has been for the request to be embodied in a joint resolution of the Senate and House of Commons. ${ }^{26}$ Whether the practice that the provinces have to be consulted in matters affecting them, and have to agree to the proposed amendment, had hardened into a convention of the Constitution, was by no means clear. If a convention is absolutely clear and certain the courts may assimilate it into the law of the constitution. As Sir Kenneth Wheare put it, if a court recognizes a constitutional custom "as it will apply it in the determination of a dispute before it, then

22. K. Wheare, The Statute of Westminster and Dominion Status 153 (5th ed. 1953).

23. P. Gerin-Lajoie, Constitutional amendment in Canada 138 (1950).

24. H.C., Foreign Affairs Comm., First Report, Session 1980-1981 (Jan. 21, 1981).

25. H.C., Foreign Affairs Comm., Second RePORT, Session 1980-1981 (Apr. 15, 1981).

26. GERIN-LAJOIE, supra note 23, at 145-51. 
that custom has ceased to be a nonlegal rule, and has joined the body of law strictly so called."27 Alternatively, a court may recognize that a convention has been established but not go so far as to apply it as a judicial rule in the determination of a case. Both of these possibilities were implicit in the references to the three provincial courts of appeal, which in essence posed three questions: do the Trudeau proposals affect provincial powers; is there a convention that such amendments will not be proceeded with without provincial consent; and is provincial consent a legal requirement of the Constitution? The answers of the three provincial courts of appeal were various. The Manitoba court upheld the position of the federal government in a 3-2 decision, ${ }^{28}$ and the Quebec court reached the same conclusion by a majority of $4-1,{ }^{29}$ while the Newfoundland court was unanimous in supporting the provincial position. ${ }^{30}$ In the Supreme Court of Canada the appeals from the three decisions were taken together, even though the questions were somewhat differently worded.

It should be noted that the merits of the specific parts of the Trudeau proposals were not directly before the courts in the various references. Nevertheless it was the proposals themselves, as much as the procedure, which in varying degrees stiffened the resistance of the various provincial governments to the whole process.

A major constitutional issue created by the Trudeau constitutional proposals concerns the "entrenchment" of a Bill of Rights in the Constitution. The effect of the Bill of Rights is, of course, to set up a constitutional barrier against legislation by either level of government which transgresses its norms. As the dissenting provinces see it, the effect of this is to take away legislative powers which they now possess under the Constitution without their consent. The federal reply is that, whatever the Bill of Rights does, it does not alter the federal balance of the Constitution since it equally restrains both levels of government from abusing their legislative powers in an unconscionable manner. For public consumption the Bill of Rights is described as a "people package" which has nothing to do with the distribution of power in the Constitution.

Probably the most sensitive part of the Bill of Rights is the part which deals with minority language rights. It reasserts existing constitutional rights to the use of French and English in the legislatures and court of Canada, Quebec and Manitoba (and adds New Brunswick at its request), it entrenches the federal Official Languages Act (which entitles Canadians to be served by the federal government in either of the two official languages), and it puts into the Constitution the right of linguistic minorities of either language group to educate their children in that language. This would not only provide a constitutional guarantee of such rights where Francophones are already a substantial minority, and already fairly well served in practice, as in New Brunswick and Ontario, but create an obligation of a new sort on provinces where such minorities are smaller. In Quebec, where the substantial recognition of minority school rights in the English language depends

27. WHEARE, supra note 22 , at 2 .

28. Reference Re Amendment of the Constitution of Canada, 117 D.L.R.3d 1 (1981).

29. Reference Re Amendment of the Constitution of Canada, 120 D.L.R.3d 385 (1981).

30. Reference Re Amendment of the Constitution of Canada, 118 D.L.R.3d 1 (1981). 
on constitutional guarantees to religious minorities, this right would be reasserted on the firmer ground of language. The effect, when this part is intended to come into force (three years after the coming into effect of the new Constitution Act), would be to nullify an important part of Quebec's language law, commonly called Bill 101.31 That Act declared French to be the official language of Quebec and extended the right of schooling in English only to children of parents educated in that language in Quebec. To the present government of Quebec, which regards this legislation as the keystone of its policy of protecting the survival of the French language and culture, the Bill of Rights presents a potent threat to its essential powers under the Constitution.

The objection to the Bill of Rights in the western provinces is of a different order. To the Premier of Manitoba, and to perhaps a lesser extent to the others, an entrenched Bill of Rights is a direct challenge to constitutional values. He adheres to the traditional English common lawyers' view, once so fully articulated by Dicey, that the rights of the citizen are best protected by the common law and not by putting the courts in a position to erode the sovereign power of the legislature which is the foundation of the Westminster system of government. To this argument many Westerners would add that taking power from the people's representatives and giving it to the courts is to negate democratic principles by transferring the power to prescribe the basic values of the community from elected representatives to nonelected judges. To them it is a confrontation between democratic and elitist values.

The Trudeau proposals have involved a third area of contention by the inclusion of an amending formula. Obviously any attempt at patriation would have to deal with this matter, since there is no point in leaving the situation in limbo with no authoritative method for making changes in the future. The Trudeau solution was to adopt, as an interim measure, the formula so nearly achieved at the Victoria Conference in 1971, which in essence required the consent of the Parliament of Canada, of any province having 25 percent of the population (i.e. Ontario and Quebec), and at least two of the four provinces having at least 50 percent of the population in each of the other regions (Western Canada and the Atlantic provinces). If they had been content with this proposal there would have been some objection, but probably not from most of the provinces. However, the Trudeau package included a number of controversial additions. A new amending formula could be adopted by unanimous consent within two years. There were further provisions which suggested the possibility that amendments and the amending procedure could be secured by the use of referenda if provincial governments proved to be recalcitrant. Provincial governments as well as those who dislike referenda on principle objected to these provisions. The provinces feared that their positions, supported by their legislatures, could be overridden by referenda which were not under their control. The amending formula proposed by the federal government also included a new provision (since dropped) which would have given the Senate a suspensive rather than an absolute veto in the amending process. The

31. The Charter of the French Language, Que. Rev. STAT. c. 11 (1977). 
reason for this was the ongoing constitutional discussions in recent years which have included proposals for a radical revision of the role and composition of the Senate in the federal system. ${ }^{32}$

Every discussion of constitutional reform since 1927 has ended in disagreement. In the present case the federal government is seeking to break out of the stalemate by taking the initiative in hopes that the force of public opinion will neutralize the opposition. It is fairly clear that they foresaw that the furious round of preparatory negotiations would fail, and that the first ministers would not reach agreement in September. Meanwhile they had armed themselves with an outside legal opinion from counsel that there were no legal barriers in the way. In this respect the federal government has been vindicated in the supreme court.

The question arises as to why the federal government-to shorten the legal debate-did not launch a preemptive strike of its own by referring the matter directly to the Supreme Court of Canada by way of reference. This would have had the advantage, often useful, of enabling them to frame their own questions. The answer to this, given early in the discussion by a federal minister and reiterated since by the Prime Minister, is that such a course would have indicated that they had doubts about the legality of their course. There is, however, another question besides legality involved, and that is propriety.

Critics of the federal action are prone to quote from an earlier Minister of Justice, the Hon. Guy Favreau, who in proposing the aborted formula of 1965 said:

The Constitution cannot be changed in a way that might deprive the provinces of their legislative powers unless they consent. The law has not said so, but the facts of national life have imposed the unanimity requirement, and experience since Confederation has established it as a convention that a government or Parliament would disregard at its peril. ${ }^{33}$

Why was "a fact of national life" in the considered view of the Government of Canada in 1965 no longer a fact of life in 1981? In part the answer is that what was a matter of reconciling conflicting, but not utterly opposed, interests between the two levels of government is now a conflict not so easily reconciled between two views of Canada. This conflict was characterized by Prime Minister Trudeau as one between those who regarded Canadian federalism as something less than the sum of its parts and those who think that it is something more. The speeches of some premiers make it clear that Canada is, to them, a confederal arrangement in which the provincial components are the integral units and the federal government is merely charged with limited common responsibilities by them. This view, needless to say, is that of the Quebec government, which claims within its territory to be the only legitimate government for Quebeckers. Against this view there is ranged a federal government with a firm majority in the House of Commons (a comparatively rare thing these days) imbued with a sense that the Canadian system has become already "the most decentralized federal system in the world" at a

32. See, e.g., The Task Force on Canadian Unity, A Future Together (1979). Several provincial governments, as well as the Canadian Bar Association, have taken a position in favor of similar proposals.

33. G. Favreau, The amendment of the Constitution of Canada 47 (1965). 
time when economic conditions require central governments with the power and authority to take strong measures.

The extent to which the protagonists are willing to resort to the courts is evidence of the escalation of the conflict. It has been noted that this was an expedient to be avoided at all cost during the height of executive federalism, when both sides gained sufficiently by negotiation to make the risks of litigation too high to be considered. Furthermore, a major role in determining what the Constitution means is not one that Canadian judges relish. They do not see themselves as legislators. ${ }^{34}$ Their preferred role, to which they are suited by temperament and training, is that of "black-letter" lawyers immersed in the niceties of statutory interpretation and eschewing broad principles when a narrow construction will suffice. This is illustrated in their handling of cases under the Canadian Bill of Rights of 1960-a federal law which appears to override any federal law that is inconsistent with it. With few exceptions they have held that the rights asserted can be remedied under the provisions of another statute, such as the Criminal Code, so that it becomes unnecessary to consider the wider question of whether the Bill of Rights applies. ${ }^{35}$ Addressing themselves to fundamental questions of constitutional values is not a congenial prospect.

In taking this position it is probable that they have some wisdom on their side. It is likely that the Supreme Court of Canada is aware that its authority in such matters is fairly tenuous. The entrenchment and/or reform of the court has been on the public agenda for years. There are even influential advocates, particularly in Quebec, of the establishment of a purely constitutional court; constructed on "representative" lines. Such a court, if it divided (as it might well) according to the value differences of its various constituencies, would only exacerbate the very differences it was established to settle. Furthermore, constitutional law is not readily separated form other branches of law, and issues of substantial constitutional import are likely to arise as part of a wide variety of what are nominally civil disputes. The present court appears to be going out of its way to avoid being split on issues of constitutional principle. Sometimes these are unavoidable, as was the case in the Anti-Inflation case, ${ }^{36}$ which brought out two Francophone judges in strong dissent from the majority of the court. Apparently a successful closing of the ranks was achieved in the Senate Reference, ${ }^{37}$ where the court took the unusual step of issuing "for the Court" a unanimous and unattributed judgment. ${ }^{38}$ There were undoubtedly efforts to achieve the same result in the questions on the constitutional amending resolution, but they failed. However, in any event the three judges from Quebec were not isolated but were incorporated into the majority.

34. For the views of the present Chief Justice of Canada, who is more of a judicial activist than most of his brethren, see Laskin, The Judge as Legislator and Administrator, 1973 TRANSACTIONS OF THE ROYAL SOC'Y OF CAN. 183.

35. See W. Tarnopolsky, The Canadian Bill of Rights 128-63 (2d ed. 1975).

36. Reference Re Anti-Inflation Act, 68 D.L.R.3d 452 (1976).

37. Reference Re Legislative Authority of Parliament to Alter or Replace the Senate, 102 D.L.R.3d 1 (1979).

38. See Hogg, Constitutional Law: Federal Power to Amend the Constitution of Canada-Reform of the Senate, 58 CAN. BAR. Rev. 631 (1980). 
Something should be said at this point about reference cases. The Parliament of Canada and all provincial legislatures have made provision for the executive to seek advisory opinions from the courts. About one-third of judicial rulings on $\mathrm{Ca}$ nadian constitutional questions have in fact been based on such references. Since there is no strict separation of powers in the Canadian Constitution, there is no constitutional barrier to this device, which is not available as far as the Supreme Court of the United States is concerned, and has been also rejected by the High Court of Australia ${ }^{39}$ Such decisions may not be as authoritative as decisions arising out of normal litigation, but they have in fact been treated as equally authoritative by Canadian courts. A direct reference to an appellate court has the obvious advantage of cutting short the period of legal doubt which would be created while a case wound its way slowly up the hierarchy of courts. It has two disadvantages. It is disliked by the judiciary because it compels them to reach a decision in the absence of the wider range of considerations which would be a visible if they had a real dispute between parties over the text of an actual law (a reference case may involve not only general questions but often an actual bill or statute). The second disadvantage is that it confers a special advantage on the executive simply because the answer one gets depends to some extent on the wording of the question which is asked.

In 1981 the reference cases decided by the Manitoba, Quebec and Newfoundland courts, which raised the three crucial questions were heard and decided. The Supreme Court of Canada, having heard argument on the appeals at the end of April, mulled over the questions over the summer and finally delivered judgment on September $28 .{ }^{40}$ The court had no difficulty with the first question. They were unanimous in finding that the Trudeau proposals did in fact affect the rights and powers of the provinces. ${ }^{41}$ On the second question the court was divided. The six justices in the majority found that there was indeed a constitutional convention which had been established that substantial provincial consent must precede a resolution seeking amendments which affected provincial rights and powers, but unfortunately they failed to "quantify" the degree or kind of consent required.42 The three dissenters, including the Chief Justice, found that no such convention existed. ${ }^{43}$ The answer to the third question was divided by the court into two parts. The majority felt that the proposed amendment package violated the norms of the Constitution established by convention. ${ }^{44}$ Nevertheless, seven of the justices ruled that the federal government's action was legal. ${ }^{45}$

The supreme court's decision has not left the situation much clearer. The court has found a convention of the Constitution which Canadians did not know existed (even though the principal actors had apparently conducted themselves in the past

39. P. Hogg, Constitutional Law of Canada 130 (1980).

40. Reference Re Amendment of the Constitution of Canada, 125 D.L.R.3d 1 (1981). The questions posed are discussed at notes 28-30 supra and text accompanying.

41. Id. at 20 .

42. Id. at 79-107.

43. Id. at 107-27.

44. Id. at 20-49.

45. Id. at 47 . 
in conformity with it) in disposing of a case in which one of the principal issues was an amendment which would have substituted a legal amending formula involving provincial participation, but they have failed to specify what the convention is. What number of provinces constitute "substantial" compliance with the convention? Is this provincial consent to be signified by provincial legislatures, or is it sufficient for governments alone to consent? They do not say. The two judges who supported both the existence of the convention and the consequence that the whole thing was illegal were at least consistent, as were the three who found no convention and no illegality. The four who recognized the existence of the convention and also made up the majority who found the package legal have been responsible for the resulting confusion as to what in fact the court has decided.

The outcome in the first instance has produced a flurry of informal discussions between the provincial and federal governments in search of a compromise. Will the eight provinces, or some of them, be willing to reach an accommodation which the federal government will accept? Perhaps, but at the time that this is written the outcome does not seem promising. Meanwhile in Great Britain those who had hoped that the supreme court ruling would dissipate opposition have been disappointed.

\section{$\mathrm{V}$ \\ CONCLUSION}

Stripped to its essentials the whole dispute goes to the root of the Canadian constitutional arrangement. At stake are different views of both the purpose of the union and the distribution of power within it. For different reasons Quebec and the western provinces are demanding substantial modifications of the powers of the federal Parliament over such key matters as communications, commerce and resource management. One of the strongest bargaining counters possessed by the provinces has been their power to delay constitutional change. There is no doubt, for example, that the capacity of the federal government to use its existing powers to deal with the energy crisis is hampered by jurisdictional disputes over resource management with the oil producing provinces, which seek a significant surrender of federal powers. So we are back at the Constitution again.

The most obvious thing about the present impasse, involving a complex balance of political forces, is that the Canadian version of that much talked about problem of "ungovernability" is taking its usual Canadian form-a debate about the constitution. No constitution can work if the political system cannot manage conflict within an accepted set of rules and appropriate institutions to settle disputes. The First Ministers' Conference had failed as a device for solving the constitutional impasse on patriation and the amending formula. There seems little likelihood that it can successfully manage the more complex problem of jurisdictional modification required by both western and Quebec demands. Similarly, the Supreme Court of Canada-in a decision which both sides won and both sides lost - demonstrated again that clear and authoritative answers from the courts are hard to get when political cleavages run deep and value conflicts seem to defy reconciliation. 